\title{
Effectiveness of the Use of the Construction Pattern Module in the Fashion Study Program of Medan State University
}

\author{
Farihah $^{1}$, Dina Ampera ${ }^{2}$, Surniati Chalid ${ }^{3}$ \\ \{farihah34@gmail.com ${ }^{1}$ \} \\ Universitas Negeri Medan, Indonesia ${ }^{1,2,3}$
}

\begin{abstract}
The purpose of this study is to find out how far the effectiveness of the use of modules can provide benefits to knowledge, technology, skills, discipline and work ethic and creative attitudes, students of the Fashion Design Education Study Program. This is behind the quality of the graduates of Fashion Design in implementing in school success standards and out-of-school success standards. The first criteria includes aspects of student success in fulfilling curricular demands that have been oriented towards the demands of the workforce. While the second criterion includes the success of students who are skilled in performance skills in accordance with national or international learning outcomes after they are in actual employment. Based on the results of the research carried out, the results can be taken by using modules on competency to change the pattern according to the design, overall obtaining an assessment in good fierce criteria, and overall material experts assess the results in very good criteria. The results of student questionnaire responses on the Construction Module Pattern in the criteria strongly agree if the module can attract attention, increase interest in learning, motivate and look attractive so that the module is declared effective to be used as a learning medium in learning Pattern construction for Fashion Design students. The research instrument used in the study is the instrument of student response to modules and learning outcomes test instruments. The scale used for student responses to modules is a Likert scale. Data analysis techniques used are descriptive and inferential statistical data analysis. Learning outcomes of students with pattern construction modules with an average of 81.25 . The average student learning outcomes in the high category.
\end{abstract}

Keywords: Pattern Construction Module.

\section{Introduction}

Vision and mission Clothing Study Program is to provide knowledge, technology, skills, discipline and work ethic and creative attitude, and as one of the sources of producing skilled workers in the fashion sector so that skilled and qualified resources will soon be able to fill various jobs in business and industry. This is in accordance with the function of national education, namely developing the ability and shape of dignified national character and civilization in order to educate the lives of the nation, aiming at developing the potential of students to become believers and devoted to God the Almighty, noble, healthy, knowledgeable, capable, creative, independent and become a democratic, personality, and work-oriented citizen and responsible and productive. 
According to Syah (2009) there are several factors that can influence student learning which are divided into three types, namely: internal factors of self in students, external factors from outside the student, the next factor is the approach to learning, namely ethnic learning students that include strategies, models, media used and this of course requires teachers who are able to teach. In this regard, Sanjaya (2010) suggests that lecturers as educators have an important role in the learning process, namely 1) as a learning resource, 2) as a facilitator, 3) as manager, 4) as a demonstrator, 5) as a mentor, 6 ) as a motivator. While learning is a conscious effort from the lecturer to direct students to interact and be supported by learning resources that are professionally and effectively delivered by the lecturer in achieving the expected goals.

Hamalik (1994) states that lecturers are required to be able to understand, use available tools in an effort to achieve the objectives of the expected learning goals. From this statement, it is implied that the lecturer must have sufficient knowledge and understanding of the learning media. Based on the initial observations that the authors did to some lecturers needed a good learning module in the learning process so that learning was more effective. Previously the lecturers only used media books, handouts, blackboards as media and only a few specific materials that used power point media. It is also known that the constraints in using the media because there are still many lecturers do not have the expertise to develop and use the media are not even familiar with computer technology, so the learning strategy is carried out conventionally. The learning system that is conducted is centered on the lecturer, namely by delivering the learning material by lecturing, the next demonstration the lecturer gives assignments or training to students. From the observations of some students it was stated that the learning media was very necessary because learning became more interesting and students could use the media as an individual learning tool.

Achievement of student learning outcomes that have not been maximized, this does not mean that students do not have the ability to draw construction patterns are suspected there are many more factors that cause low learning outcomes construction patterns such as factors within students, which include physiological factors, interests, talents, and motivation. Factors outside the student self are learning models, learning media, learning facilities and infrastructure, learning resources, approaches, techniques, tactics used during the teaching and learning process and learning strategies. However, the low learning outcomes from observations, due to lack of media use. Students are always conditioned to receive information as it is so that students become passive and wait to be given information without trying to find the information. This causes the learning atmosphere to be less attractive and communicative so that students are less motivated to learn and difficult to understand each step in the Pattern Construction course.

The Construction Pattern course is continuous learning from a complex unit. Other characteristics of these subjects in the learning process require students to do step-by-step work so as to realize the learning objectives as examples for archetypal drawing material, usually done with media handouts and with demonstrations that only focus on the lecturer during learning, but students cannot yet clearly understand and unable to repeat the process appropriately and correctly, therefore this leads to conducting research to create learning media, which makes it easy and motivating to learn independently and can repeat it if it is not understood after learning or without the presence of a lecturer. Referring to the acquisition of learning outcomes, to achieve the expected learning outcomes, learning must be carried out maximally so that all indicators are achieved. This is not only supported by lecturers who can create conducive learning for students, they also need improvements in the learning process so that students are more motivated and more active in learning Pattern Construction. Students 
easily understand the material and improve learning outcomes. One effort that can be done is by using learning media. With the use of instructional media, it is expected to be able to assist the lecturer in conveying the subject matter so that learning can run effectively and efficiently and students can more easily understand the concepts of pattern construction learning.

Munadi (2011) learning media can be understood as "everything that can deliver and channel messages from sources in a planned manner so as to create a conducive learning environment where the recipient can do the learning process efficiently and effectively. Thus, the purpose of using the media in the learning process is to streamline and streamline the learning process itself. The use of learning media allows students to adjust their speed in mastering learning. Unlike the way of direct learning, generally the speed of learning comprehension is determined by the lecturer, so it can be seen that the learning media is very influential in the effectiveness and efficiency of learning.

With the use of learning modules, it is expected that students will easily absorb the material, so that they will achieve the expected educational goals. Learning effectiveness is facilitated by the development of learning modules. In this study the Pattern Construction Module developed which serves to overcome weaknesses in learning media. Handoyo (2003) says that the module is the presentation of information in the form of text, images and sound integrated so that it becomes effective and efficient. Modules can stimulate human senses and are very influential on student learning outcomes as expressed by Munir(2008) that approximately $90 \%$ of one's learning outcomes are obtained through the senses of view, 5\% through the senses of hearing and $5 \%$ through other senses. Thus the appearance of the packed learning module becomes more attractive because there are pictures of fashion patterns in it. Through the Construction Pattern module students are expected to be more interested in learning and motivated in participating in learning.

\section{Theoritical Study}

\subsection{Fashion Pattern Construction}

Fashion patterns a piece of paper that is a prototype of clothing parts or sewing products. Pratiwi (2001) states that patterns are pieces of cloth or paper that follow the size or shape of a particular body. This statement is supported by the opinion of Muliawan (2002) who defines a pattern or pattern in the field of sewing as a piece of cloth or piece of paper used as an example to make clothes when the material is cut. The pattern is used as an example so that no errors occur while cutting fabric. In addition to using homemade patterns, people can sew at home using ready-made patterns (finished patterns) published by women's magazines.Pratiwi, (2001) states that archetypes can be divided into several types based on their manufacturing techniques, their parts, methods and types. Fashion patterns based on manufacturing techniques can be divided into 2 types, namely:

Draping pattern is a pattern made based on a person's body shape and then gives folds on the ballooned and unwanted part. When finished, the cloth or paper is removed from the body and flattened in a flat place, and the marks are marked. When finished, the cloth or paper is removed from the body and flattened in a flat place, and the crease marks are marked. This pattern was used before the construction pattern was found and is still used by fashion designers who use a high-level settlement system. The construction pattern is a pattern for making a pattern of clothing that is basically dior pattern can be with a pattern drawing with a 
systematic calculation. This pattern is based on individual bodies. Making it is complicated and takes longer to create this pattern.

Pratiwi (2001) argues that the basic pattern according to its parts can be divided into 3 types, namely: a) Agency Patterns; The basic pattern of the upper body, which is the pattern of the body starting from the shoulders, neckline to the waist. The basic pattern of the body is divided into two, namely the pattern of the body of the face and the pattern of the back body, b) the Basic Pattern of the Skirt; The basic pattern of the skirt, which is the basic pattern from the waist down to the knee or to the ankles, and c) Basic Patterns of the Arm The basic pattern of the arms, namely the pattern of the upper arm to the elbow, wrist or the desired length of the arm.

\section{$2.2 \quad$ Module Effectiveness}

According to Sudjana (1990) that effectiveness is a learning process with regard to the paths, efforts, techniques, and strategies used in achieving goals optimally, appropriately, and quickly. Furthermore, effectiveness is defined as showing the level of achievement of a goal.A business can be said to be effective when the business reaches its destination. Thus explained that the effectiveness shows more on the specific results, namely the effectiveness shows the success in terms of whether or not the target is achieved. Learning effectiveness is important to measure in order to know the extent to which goals have been achieved.

For lecturers, student learning effectiveness is a measuring tool to assess success, not the teaching and learning process that has been carried out, while students have an interest in knowing the effectiveness to measure the extent to which students master the material taught by the lecturer. Lecturers must pay attention to various things that can affect the achievement of effectiveness and conduct evaluations at any time so that it can affect the extent to which students have been able to accept and master the material that has been displayed. Learning effectiveness is the level of achievement of learning goals. The achievement of these objectives in the form of increased knowledge and skills and the development of attitudes through an educational learning process. Learning effectiveness has the following aspects: increased knowledge, increased skills, improved attitudes, improvement in student achievement and behavior. Accurate measurement of achievement is very important, because lecturers cannot help students effectively if they do not know the skills and knowledge of the students and what material is the problem. The achievement of students was intended so that knowledge and skills can be mastered by students as a result of Surakhmad's (1994) experience, factors that influence effectiveness include the ability of lecturers to use learning media. The use of learning media is influenced by the objectives, students, situation, facilities and instructors themselves. The better and more precise the use of a method and media, the more effective the achievement of the goals that have been set, so that the learning outcomes are better. Effective learning is determined by its use. Because, the learning process shows a high percentage of student involvement in the right time, so that the achievement of goals is achieved by good student attitudes. Thus it can be said that the effectiveness of the process of learning objectives on target in accordance with the goals set.

Purwanto (2007) Modules are learning materials that are designed systematically based on a particular curriculum and are packaged in the smallest learning unit and allow to be studied independently in a certain time unit. The goal is that participants can master the competencies taught in training or learning activities as well as possible. Its function as learning material used in learning activities of students. 
Module teaching is carried out according to the rules of the implementation guidelines that are able to contribute in order to improve achievement / learning outcomes, so that in learning the principles with the module needs to be considered. The achievement of goals by students is an effect of how the module in According to James D Russell (1992) the principles in module learning are as follows: 1) Modules using independent instructional packages, meaning that they are studied individually or in groups of the same age through multisensory learning observations with student order maximally 2) Modules within normal limits are very suitable for individual differences, even though the teacher simultaneously serves all the needs of students 3) Modules are prepared on the basis of special instructional goals, the modules are very realistic, accessible to every student who learns them with all the characteristics he has 4 ) Modules using the concept of association structure and sequence of knowledge 5) Modules using a variety of relevant tools and media 6) Modules portray active students participating in learning 7) Modules always encourage students to monitor certain responses 8) Modules using knowledge mastery strategies thoroughly. In accordance with the above module principles, it can be seen that the teaching of modules opens opportunities for students to learn according to their respective speeds and ways, therefore they use different techniques to solve certain problems based on their individual knowledge

\section{Research Methods}

This research is a research and development ( R \& D) was carried out on the Construction Course for Fashion Design Education Study Program at UniversitasNegeri Medan, which uses the development of the Dick and Carry Model in the Pattern Construction course, namely the development of the Dick and Carry model in the Pattern Construction course. The initial step of this research is; conduct preliminary research, which includes: (a) identification of learning needs and determining competency standards for courses; (b) conducting learning analysis (c) identifying the characteristics of students; and (d) writing basic competencies and indicators (e) writing benchmark reference tests, (f) developing learning strategies that are realized in the form of syllabi and learning designs; ( $\mathrm{g}$ ) developing learning materials.

The data extracted are as follows: (1) the learning aspects and the truth of the contents are obtained from the material experts and the design of the learning model, (2) the attractiveness of learning is obtained from the activities and responses of students during the learning trial with Dick and Carrey in the Pattern Construction course.

The instruments used in this study were (1) questionnaire needs of lecturers and students, (2) questionnaire sheets for material experts; used to obtain data about the quality of learning materials and the development of aspects of the learning delivery system filled by the lecturer, (3) questionnaire for learning design experts; used to obtain data about the quality of the learning and technical design of the product in the form of design development of Construction Pattern learning by learning design experts, (4) observation test sheets; which is used to obtain data about the results of Pattern Construction learning.

Data analysis is done on the initial data obtained and on the data of the initial product development validation results by experts. With this descriptive technique, the researcher describes the collected data as they are without intending to make conclusions that apply to the general or generalization (Sugiyono, 2010). In the module needs analysis phase, the researcher describes the material needs of the construction pattern. In the validation phase of the initial product development by experts, researchers described the results of the research and 
validation from the expert level of feasibility of the learning design. The results of the student's assessment of module design, by describing, the score or mean (Mean), Median (Md), Mode (Mo) and standard deviation or standard deviation (SDi).

\section{$4 \quad$ Research Results And Discussion}

The results of the needs analysis obtained answers that from 3 Pattern Construction lecturers (100\%) answered the Module had never been in Pattern Construction. While the needs data distributed to 31 semester 1 students $(51 \%)$ stated strongly agree that the pattern drawing module was not too popular in pattern construction learning.

The collection of learning material is intended so that the presentation of the material in the module does not deviate from the curriculum used. In the pattern construction course, the basic competencies change the pattern according to the design. The main material taught in the pattern construction course is changing the pattern of the blouse according to the design, changing the pattern of the shirt according to the design, changing the skirt pattern according to the design.

The results of the analysis by media experts and material experts in each aspect of the assessment as a whole are determined by the score, then analyzed to determine the feasibility of developing the module. As for the percentage of the results of the assessment of media experts as follows in the aspect of module display, aspects of efficiency, and aspects of technical quality, the effectiveness of the module is summarized below;

Table 1. Results of the average percentage of assessment of the development of pattern construction modules by media experts.

\begin{tabular}{llcc}
\hline No & Indicator & Average & Criteria \\
\hline 1. & $\begin{array}{l}\text { Module display } \\
\text { aspects }\end{array}$ & 90 & Very Good \\
\hline 2. & Efficiency aspect & 80 & Good \\
\hline 3. & $\begin{array}{l}\text { Technical quality } \\
\text { aspects, module } \\
\text { effectiveness }\end{array}$ & 90 & Very good \\
\hline & Average & 86,67 & $\begin{array}{l}\text { Very } \\
\text { Good }\end{array}$ \\
\hline
\end{tabular}


Based on the assessment of media experts, the development of Modules in the overall pattern construction course is very good and feasible to use in the learning process but there are several suggestions and inputs to improve the feasibility of the module products. The results of the analysis of suggestions and input expressed by media experts are as follows: 1) Image selection, 2) Need to add module usage instructions, 3) In the reference menu, you should not use 1,2, and 3 points for bibliography, 5) Adjust layout of images, letters and arrangement in module products.

Table 2. Results of an average percentage of assessment of the development of the Pattern Construction module by material experts.

\begin{tabular}{llcc}
\hline No & Indicator & Average & Criteria \\
\hline 1. & Learning Aspects & 94 & Very Good \\
\hline 2. & $\begin{array}{l}\text { Aspects of } \\
\text { Accuracy of } \\
\text { Material }\end{array}$ & 85 & Very Good \\
\hline & Average & 89,5 & Very Good
\end{tabular}

The assessment of material experts said that the development of the Construction Pattern module as a whole was considered very good and feasible to be used in the learning process but there were some suggestions and inputs to improve the feasibility of the module product. The analysis of suggestions and inputs put forward by the expert learning material is as follows: 1) Pattern lines are less clearly visible on the application pattern, 2) The pattern making method is good but the application is not correct. 3) Before the pattern creation application is displayed, the design analysis is explained first.The results of small group trial data analysis on each aspect of assessment as a whole are determined from the average score in each category. The results of the study were then analyzed to determine the shortcomings of module products.

Table 3. Results of the average percentage of response assessment for the development of Pattern Construction modules in small group trials.

\begin{tabular}{llcc}
\hline No & Indicator & Average & Criteria \\
\hline 1. & $\begin{array}{l}\text { Attractive aspects } \\
\text { of the module }\end{array}$ & 61,33 & enough \\
\hline 2. & $\begin{array}{l}\text { Aspects of the } \\
\text { level of difficulty } \\
\text { in using modules }\end{array}$ & 62 & enough \\
\hline 3. & $\begin{array}{l}\text { Module display } \\
\text { aspects }\end{array}$ & 61,6 & enough \\
\hline 4. & $\begin{array}{l}\text { Aspect benefits of } \\
\text { the module }\end{array}$ & 66 & enough \\
\hline & Average & 63 & enough \\
\hline
\end{tabular}


The results of the assessment on the development of the Pattern Construction module show that the products developed are still in the "sufficient" criteria so that the development is continued in the medium group trial at the second revision.

Table 4. The results of the average percentage of assessment responses to the development of Pattern Construction modules in the medium group trials.

\begin{tabular}{llcc}
\hline No & Indicator & Average & Criteria \\
\hline 1. & $\begin{array}{l}\text { Attractive aspects of } \\
\text { the module }\end{array}$ & 76 & Agree \\
\hline 2. & $\begin{array}{l}\text { Aspects of the level } \\
\text { of difficulty in using } \\
\text { modules }\end{array}$ & 70,67 & Agree \\
\hline 3. & $\begin{array}{l}\text { Module display } \\
\text { aspects }\end{array}$ & 74,66 & Agree \\
\hline 4. & $\begin{array}{l}\text { Aspect benefits of } \\
\text { the module }\end{array}$ & 76,66 & Agree \\
\hline & Average & 74,49 & \\
\hline
\end{tabular}

The results of the assessment on the development of the Construction Pattern module as a whole are stated "agree" and can be continued in the field group trial. The results of the data analysis in the field group trials conducted on 31 students who were attending the Construction Pattern lecture on each aspect of assessment are described in table 5 below.

Table 5. The results of the average response assessment on the development of the Pattern Construction module in the field group trial.

\begin{tabular}{llcc}
\hline No & Indicator & Average & Criteria \\
\hline 1. & $\begin{array}{l}\text { Attractive aspects } \\
\text { of the module }\end{array}$ & 92,67 & $\begin{array}{c}\text { strongly } \\
\text { agree }\end{array}$ \\
\hline 2. & $\begin{array}{l}\text { Aspects of the } \\
\text { level of difficulty } \\
\text { in using modules }\end{array}$ & 87,5 & $\begin{array}{c}\text { strongly } \\
\text { agree }\end{array}$ \\
\hline 3. & $\begin{array}{l}\text { Module display } \\
\text { aspects }\end{array}$ & 91 & $\begin{array}{c}\text { strongly } \\
\text { agree }\end{array}$ \\
\hline 4. & $\begin{array}{l}\text { Aspect benefits } \\
\text { of the module }\end{array}$ & 91 & $\begin{array}{c}\text { strongly } \\
\text { agree }\end{array}$ \\
\hline & Average & 90,54 & $\begin{array}{c}\text { strongly } \\
\text { agree }\end{array}$ \\
\hline
\end{tabular}

The results of the evaluation of the module development in the Pattern Construction course in general the response value of the Strongly Agree students so that no more revisions were made. This can be seen from the small group test, the medium group trial and the large group trial experienced an increase from the student responses in Figure 1 below. 


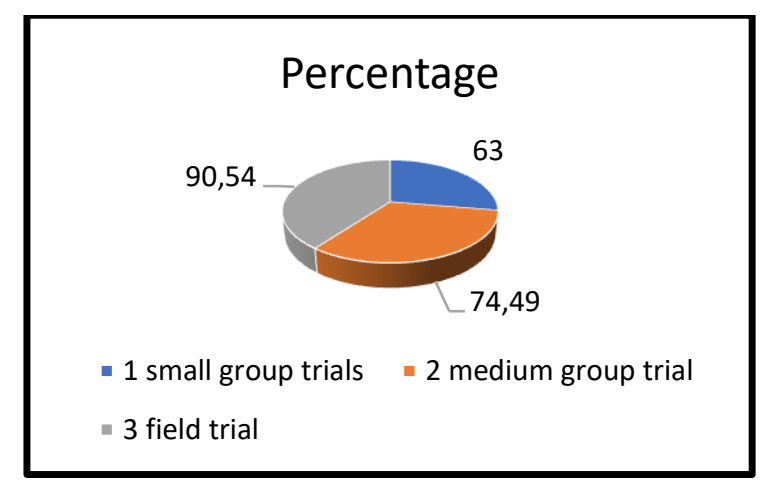

Fig. 1. Percentage of Group Test Results

The results of the data analysis of the effectiveness test are carried out to find out which products are made feasible or not used as learning media. The effectiveness test is carried out on students and Pattern Construction lecturers. Based on the results of the data analysis of the effectiveness of the test on students and lecturers concluded that the development of the construction module is very effective to use in teaching and learning activities, so as to motivate students in learning which leads to increased learning outcomes.

In the development of this Module, the material described is changing the pattern according to the design with the competency that is changing the pattern of the blouse according to the design, changing the pattern of the shirt according to the design, changing the skirt pattern according to the design. The next development phase designs and produces the initial product in the form of a module with material changing patterns. In the development of the module, the outline of the media program serves to determine the title, purpose and subject matter of the material outlined in the module product. One of the psychological principles in making media is the organization of content, (Arsyad, 2013). So in the development of modules arranged and organized in several sequences as outlined in the flow chart, the order of presentation of learning material starts from the core competencies, basic competencies, indicators, goals, tools and materials for making patterns, the material of each sub competency, namely shirt, skirt, and blouse, pattern making, evaluation and summary.

Based on the results of data analysis carried out, it was stated that the module in the pattern construction course was included in a good classification which meant that it was suitable to be used as a learning medium. The intended feasibility is that module products have fulfilled the characteristics of interactive multimedia. One of the characteristics of the module is self-instructional or independent learning, (Susilana and Riyana, 2009). This is because it is very supportive in realizing production targets and efficiency that must be met by the garment industry so as to get maximum profit.

The use of patterns with different systems affects the efficiency and results of each fashion making. The accuracy of the pattern also influences the results of products in making clothes. If the pattern used in making clothes is not correct, the clothing produced is uncomfortable when worn. In making a computerized pattern there are two types of points that must be considered, namely the Curve point (curved point) and the Grading point (value point). Grading points are points when developed (made into several sizes) must be rated. Most grading points are located in a corner or corner of the image, but can also be in the middle of a line, both in a straight line and in curved lines. 
Dress pattern is a form or picture of a component or part of clothing based on a predetermined measurement. In the pattern drawings consist of lines, curves, and other signs or drawings, such as buttons, pleated marks (darts), pleated marks (pleat), direction of fibers ( base line), etc. The pattern that needs to be considered is the point of grading and point curve (Miyoto, 2011). It was concluded that the module was feasible to be used in the learning process of the construction pattern of the fashionstudents. This is in line with the research conducted by Ampera (2017), wherein the research media developed a pattern-making learning media, stated that the learning media was suitable for use as a learning medium.

\section{Conclusion}

The conclusions in this study are as follows: 1) this research develops the module, with the material for making competency patterns to change the pattern according to the design. From the results of validation by two media experts, overall obtained an assessment in good fierce criteria. Whereas from the results of the validation by two material experts, overall received an assessment in very good criteria. 2) The results of student responses to the Construction Pattern lecture module in the criteria strongly agree that the module attracts attention, adds interest in learning, motivates students and looks attractive so that the media is declared effective to be used as a learning medium for learning Pattern construction for Fashion Design students.

\section{References}

[1] Akbar, S.: Pengembangan Kurikulum dan Pembelajaran Ilmu Pengetahuan Sosial (2011)

[2] Ampera, D.: Adeobe Flash CS6-Based Interactive Multimedia Development for Cloting Pattern Making. Vol. 103. (2017)

[3] Anglada, D.: "An Introduction to Instructional Design: Utilizing a Basic Design Model" (2007)

[4] Borg, W.R Gall, M.D.: Educational Research: An Introduction 4th Edition (2003)

[5] Buhari, Bustang.: Four-D Model (Model Pengembangan Perangkat Pembelajarandari Thiagaraj (2010)

[6] Salma, D.: Prinsip Desain Pembelajaran (2007)

[7] Mulyasa, E.: Kurikulum Tingkat Satuan Pendidikan (2006)

[8] Endang, M.: Pengembangan Model Pembelajaran

[9] Richey, Rita C. \&Seels, Barbara B.: Teknologi Pembelajaran (1994)

[10] Romiszowski, A.J.: System Approach to Design and Development. Dalam Plomp, T (1996)

[11] Sanjaya, Wina.: Strategi Pembelajaran Berorientasi Standar Proses Pendidikan (2007)

[12] Seels, B. B., Richey, R. C.: Instructional Technology (1994)

[13] Soenarto.: Metodologi Penelitian Pengembangan untuk Peningkatan Kualitas Pembelajaran (2005)

[14] Sudjana, Nana.: Penilaian Hasil Proses Belajar Mengajar (2010)

[15] Sugiarto.: Landasan Pengembangan Bahan Ajar (2011)

[16] Sugiyono.: Metode Penelitian Pendidikan Pendekatan Kuantitatif, Kualitatif, dan R \& D (2013)

[17] Syah, Muhibbin.: Psikologi Belajar (2004) 